\section{Vaterlose im Vorteil \\ Männliches Erbgut verkürzt Leben}

> Dass Männer früher sterben als Frauen, scheint am Erbgut zu liegen. Japanische Forscher haben entdeckt, dass Mäuse ohne Vater länger leben als ihre Artgenossen. Sie hatten zwei Eizellen miteinander befruchtet und so den Einfluss epigenetischer Faktoren des väterlichen Erbguts ausgeschaltet. Das Ergebnis stützt die Theorien der unterschiedlichen Lebensstrategien von
Mann und Frau - schnelles Wachstum zur Fortpflanzung kontra Energie für den Nachwuchs. Im Speziellen verdächtigen die Forscher ein Gen auf Chromosom neun, das Leben der Männchen zu verkürzen. Seine Aktivität als Wachstumsbeschleuniger ist vermutlich im väterlichen Erbgut gesteigert.

Kawahara M, Kono T, Hum Reprod 2009 (online first)

\title{
$\quad$ Spermien mit Düsenantrieb
}

> Auf die Plätze, fertig, los! Für Spermien ist es entscheidend, den Sprint zur Eizelle im richtigen Moment, nämlich erst beim Eintritt in die Scheide, zu starten. Den Startschuss dazu gibt vermutlich der Übergang vom sauren Milieu im Hoden in das alkalische Mileu in der Scheide. Denn, so haben Wissenschaftler jetzt herausgefunden: Die Konzentration an Wasserstoffionen (Protonen) ist in den Spermien tausendfach höher als im weiblichen Milieu. Und ich düse, düse, düse, düse im Sauseschritt ... Bei Eintritt ins alkalische Mileu

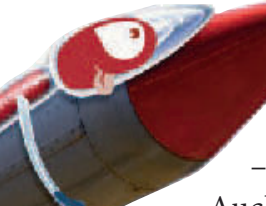
öffnen sich sogenannte Hv1-Poren, über die die Protonen herausströmen - der Startschuss für den Geißelschlag. Auch körpereigene Endocanabinoide, wie sie z. B. im Ovar im Follikel gebildet werden, fördern diesen Protonenantrieb. Dies könnte auch eine

Erklärung sein, warum Canabis-Konsum die Fertilität mindert: Die Spermien werden schon im Hoden aktiv und machen vorzeitig schlapp. Die Hv1-Poren bieten so einen möglichen Ansatz für männliche Kontrazeptiva. (ch)

Lishko PV et al, Cell 2010, 140:327

Dr. Sonja

Kempinski,

Chefredakteurin

\section{Des Mannes Unterleib ...}

... können viele Geißeln treffen. Diese bedrohen ihn zwar nicht existenziell, aber der Leidensdruck ist hoch, wenn der Penis seinen aufrechten Dienst versagt, die vergrößerte Prostata die Nachtruhe stört oder der Kindersegen ausbleibt. Last but not least kann auch der alternde Mann in die Wechseljahre kommen, und es ist wahrlich kein Spaß, wenn seine Brüste wachsen, die Libido schrumpft und das Haar schütter wird. Zumal der Testosteronmangel auch dem metabolischen Syndrom Tür und Tor öffnet. Zum Glück ist inzwischen die Männermedizin etabliert, und bei vielen Probleme im Unterleib können Andrologen, Urologen und Hausärzte helfen. Grund genug, den heißen Themen rund um den Mann einen Schwerpunkt zu widmen. Wann Männer Testosteron brauchen, wie Sie bei vorzeitigem Samenerguss raten können, wie Sie bei erektiler Dysfunktion zu spontanem Sex verhelfen und womit Sie wachsende Vorsteherdrüsen am besten bremsen, erfahren Sie in unserem Schwerpunkt ebenso wie Neues zur Verhütungsspritze für den Mann. Viel Spaß beim Lesen!

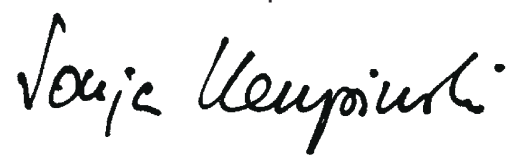

\section{Stolze Brust mit Doktors Hilfe}

> Was Frauen oft zu wenig ist, ist manchen Männern zu viel. Immer mehr Adipöse lassen sich die Brust verkleinern. So hat die Zahl der plastischen Eingriffe zur Brustreduktion in England von 323 im Jahr 2008 auf 581 im Jahr 2009 zugenommen. Bereits bei jeder zehnten kosmetischen Operation liegt ein Mann unter dem Messer. Marktführer sind aber weiterhin die Frauen - mit Brustvergrößerungen.

Pressemitteilung The British Association of Aesthetic Plastic Surgeons 1.02.2010

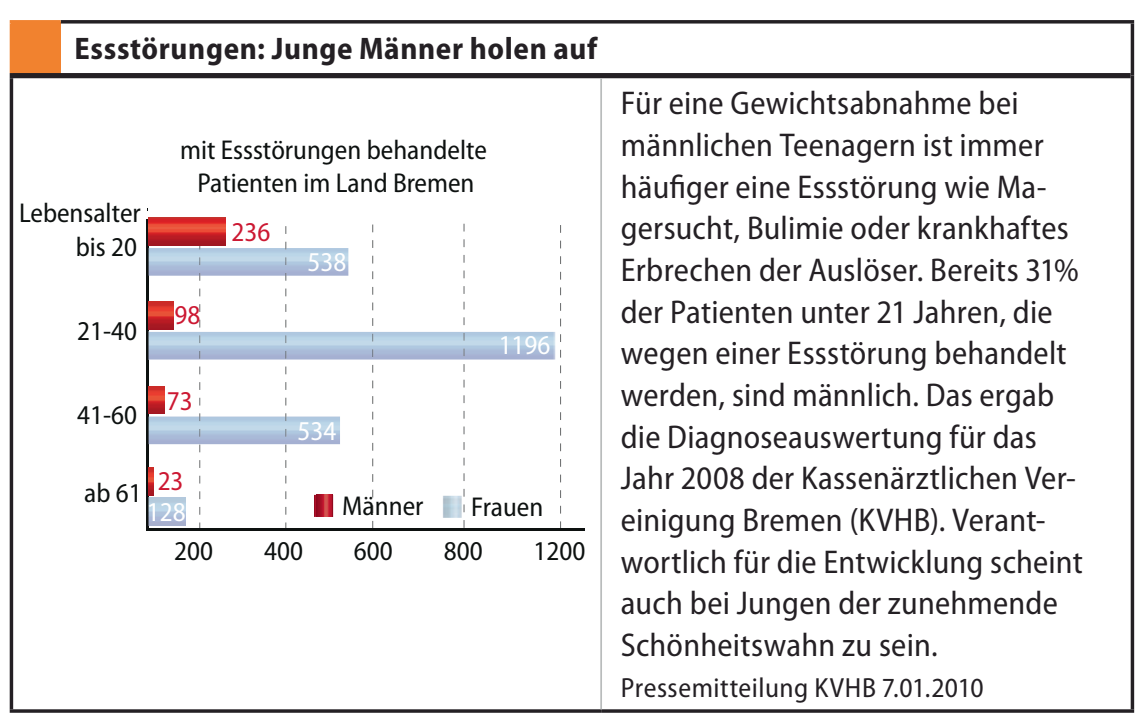

